\title{
Article \\ Biological Properties of Bee Bread Collected from Apiaries Located across Greece
}

\author{
Nikos Asoutis Didaras ${ }^{1}$, Ioannis Kafantaris ${ }^{1}{ }^{\mathbb{D}}$, Tilemachos G. Dimitriou ${ }^{1} \mathbb{D}$, Chrysanthi Mitsagga ${ }^{2}$, \\ Katerina Karatasou ${ }^{3}$, Ioannis Giavasis ${ }^{2}$ (D), Dimitris Stagos ${ }^{4}$, Grigoris D. Amoutzias 5 (D), Fani Hatjina 6 (D) \\ and Dimitris Mossialos $1, * \mathbb{D}$
}

1 Laboratory of Microbial Biotechnology, Molecular Bacteriology, Virology, Department of Biochemistry \& Biotechnology, School of Health Sciences, University of Thessaly, 41500 Larissa, Greece; didasout@uth.gr (N.A.D.); kafantarisioannis@gmail.com (I.K.); tidimitr@bio.uth.gr (T.G.D.)

2 Laboratory of Food Microbiology and Biotechnology, Department of Food Science and Nutrition, University of Thessaly, 43100 Karditsa, Greece; cmitsagga@uth.gr (C.M.); igiavasis@uth.gr (I.G.)

3 Apicultural Centre of Larissa, Federation of Greek Beekeepers Associations, 41222 Larissa, Greece; omse@otenet.gr

4 Laboratory of Animal Physiology, Department of Biochemistry \& Biotechnology, School of Health Sciences, University of Thessaly, 41500 Larissa, Greece; stagkos@bio.uth.gr

5 Bioinformatics Laboratory, Department of Biochemistry and Biotechnology, School of Health Sciences, University of Thessaly, 41500 Larissa, Greece; amoutzias@bio.uth.gr

6 Department of Apiculture, Institute of Animal Science, Hellenic Agricultural Organisation DEMETER, 63200 Nea Moudania, Greece; fhatjina@instmelissocomias.gr

check for updates

Citation: Didaras, N.A.; Kafantaris, I.; Dimitriou, T.G.; Mitsagga, C.; Karatasou, K.; Giavasis, I.; Stagos, D.;

Amoutzias, G.D.; Hatjina, F.; Mossialos, D. Biological Properties of Bee Bread Collected from Apiaries Located across Greece. Antibiotics 2021, 10, 555. https://doi.org/ 10.3390/antibiotics10050555

Academic Editor: Piotr Szweda

Received: 26 April 2021

Accepted: 8 May 2021

Published: 10 May 2021

Publisher's Note: MDPI stays neutral with regard to jurisdictional claims in published maps and institutional affiliations.

Copyright: (C) 2021 by the authors. Licensee MDPI, Basel, Switzerland. This article is an open access article distributed under the terms and conditions of the Creative Commons Attribution (CC BY) license (https:/ / creativecommons.org/licenses/by/ $4.0 /)$.
* Correspondence: mosial@bio.uth.gr; Tel.: +30-241-056-5270

\begin{abstract}
Bee bread is the only fermented product of the beehive. It constitutes the main source of proteins, lipids, vitamins, and macro- and microelements in honeybee nutrition and it exerts antioxidant and antimicrobial properties, though research on these aspects has been limited so far. In this study 18 samples of Greek bee bread, two of which were monofloral, were collected during different seasons from diverse locations such as Crete and Mount Athos and were tested for their bioactivity. Samples were analyzed for their antibacterial properties, antioxidant activity, total phenolic content (TPC), and total flavonoid content (TFC). The antimicrobial activity of each sample was tested against Staphylococcus aureus, Pseudomonas aeruginosa, Klebsiella pneumoniae, and Salmonella typhimurium. Our data demonstrate that all samples exert inhibitory and most of them bactericidal activity against at least two pathogens. Furthermore, all samples exert significant antioxidant activity, where the monofloral Castanea Sativa sample demonstrated superior antioxidant activity. Nevertheless, the antioxidant and antimicrobial activity were not strongly correlated. Furthermore, machine learning methods demonstrated that the palynological composition of the samples is a good predictor of their TPC and ABTS activity. This is the first study that focuses on the biological properties of Greek bee bread and demonstrates that bee bread can be considered a functional food and a possible source of novel antimicrobial compounds.
\end{abstract}

Keywords: bee bread; bee product; antioxidant; antibacterial; functional food

\section{Introduction}

Honeybee products (honey, bee-collected pollen, bee bread, royal jelly, beeswax, and bee venom) have been used as folk remedies since ancient times. Nowadays, depending on national legislation, they are considered foods, food supplements, superfoods, functional foods, or even complementary medicines [1-3].

Honey is definitely the most studied bee product regarding its antimicrobial properties. It is reported to exert antibacterial [4-7], antifungal [8], and antiviral activity [9-11]. In addition, it exhibits anti-inflammatory and wound-healing action [12], as well as anticancer properties [13-15]. Its antioxidant properties vary in tandem with its botanical 
origin [16-18]. Furthermore, honey is considered a prebiotic food positively affecting the human microbiome and well-being [19-21].

Bee-collected pollen (BCP) is well known for its high nutritional value, as it provides carbohydrates, proteins, essential amino acids, fatty acids (including $\omega-3$ and $\omega-6$ fatty acids), vitamins, and macro- and microelements. Furthermore, BCP contains a plethora of bioactive compounds such as polyphenols, triterpenes, carotenoids, phospholipids, phytosterols, bioactive peptides, organic acids, prebiotics, and probiotics [22-24]. Some of these compounds are secondary metabolites protecting plant male gametes, inside the pollen grains, from herbivores, pollen thieves, pathogens, and heat stress [25-27]. Others are derived from bee secretions and added microbiota [1]. This wealth of nutrients and health-promoting compounds (and possibly their synergistic action) is responsible for the antioxidant, hepatoprotective, cardioprotective, anti-inflammatory, anti-carcinogenic and antimicrobial properties attributed to BCP [28-31].

Nevertheless, the bioavailability of these compounds is not easily determined, as they are enclosed inside the walls of pollen grains, which are difficult to digest. Exine, the outermost wall of pollen grains, is made of sporopollenin, a resistant biopolymer, whereas intine, the inner layer, is made of cellulose microfibrils and pectin [32]. Therefore, in order to increase the digestibility of pollen and the bioavailability of its nutrients and bioactive molecules, bench fermentation of pollen has been attempted and several food products have been developed [33-37].

Bees have been fermenting pollen for millions of years, producing bee bread (BB) probably out of necessity to preserve pollen of high quality, which is not available throughout the year, and to increase the bioavailability of pollen nutrients. Pollen is of paramount importance to the survival of the bee colony, as it constitutes the only source of protein and lipids, and the main source of macro- and microelements [38]. Interestingly, bees prefer to feed on BB rather than freshly collected pollen.

Bees make bee bread out of pollen by adding glandular secretions to flower pollen along with some nectar from their crop (honey stomach), and at the same time they inoculate this mixture with their own microbiota [39,40]. Inside the hive, bee-collected pollen is stored in the comb cells, where it soon undergoes solid-state fermentation by lactic acid bacteria and yeasts [40-42]. As lactic acid is produced and $\mathrm{pH}$ drops, microbial succession occurs and a slower process begins: the maturation of bee bread. During maturation, the predigestion of pollen grains by added bee enzymes as well as enzymes produced by the bee-bread microbiome increase its nutritional value [40]. In this context, it is tempting to assume that the diverse bee-bread microbiota, which also serves as bee food, produce not only enzymes but also amino acids, vitamins, and antimicrobial compounds, thus enhancing the bioactivity of bee bread [43-46].

In order to elucidate how chemical composition differences might affect nutrient content and bioavailability, BCP and BB samples collected simultaneously from the same hive should be analyzed for comparison. In that regard, Anđelković et al. [47] showed that the content of crude protein was increased by $19.91 \%$ in BB compared to BCP. Using a different approach, Kaskonie et al. [43] reported that the total phenolic and flavonoid content as well as the radical scavenging activity increased by $1.27-2.40$-fold in $\mathrm{BCP}$, following fermentation.

Taking into account different published studies, BB is at least as nutritious and bioactive as BCP. It is regarded as a functional food with health benefits and therapeutic applications similar to those of pollen [2,3,48]. According to Kieliszek et al. [48], BB is more potent than pollen and therefore is usually administered in smaller doses or for a shorter period of time. Nevertheless, in health-food markets, BB is significantly less available than pollen, which is much easier to collect from the bee hive. The last few years' research regarding antimicrobial and antioxidant BB properties has started to attract attention [1,49-52].

The biological (antimicrobial, antioxidant) and nutritional properties of $\mathrm{BCP}$ and $\mathrm{BB}$ are directly related to their composition, which in turn is directly related to their botanical origin [53,54]. This is the case for other bee products such as honey or even beeswax [55-58]. 
Greek flora is characterized by high biodiversity, as it comprises 5885 species and 2000 subspecies, representing 6760 taxa. Of these, 1061 species, 411 subspecies, and 31 varieties are endemic, a total of 1442 taxa [59]. The aim of this study was to assess for the first time the antibacterial and antioxidant properties of BB samples collected from apiaries located across Greece and attempt to correlate them to botanical origin.

\section{Results}

\subsection{Palynological Analysis}

Palynological analysis was performed in all 18 samples in order to investigate whether there is any correlation between the antioxidant, antimicrobial activity and the botanical origin. Table S1 demonstrates the pollen grain content (\%) for each sample. Sample 18 was found to be monofloral (99.8\% Castanea sativa from Mount Athos). Moreover, sample 13 could be considered monofloral (Cistus spp. 78\%). Clearly dominant plant species/genus were identified in sample 5 (Hedera helix 52.,4\% and sample 11 (Borago spp. 54.8\%). Sample 8 consisted of pollen grains belonging mainly to the Brassicaceae family.

\subsection{Antioxidant Activity}

Table 1 presents the $\mathrm{IC}_{50}$ values of DPPH and $\mathrm{ABTS}^{\bullet+}$ radical scavenging assays employed to assess the antioxidant activity of $\mathrm{BB}$ samples. The lower the $\mathrm{IC}_{50}$ value, the higher the antioxidant capacity. Regarding the DPPH assay, the $\mathrm{IC}_{50}$ values ranged from 0.18 (sample 18) to $1.8 \mathrm{mg} / \mathrm{mL}$ (sample 2). Besides sample 18, strong DPPH radical scavenging activity was observed for BB samples 9, 6, 7, and 3. Furthermore, BB samples 4 , 11,16 , and 17 demonstrated similar DPPH radical scavenging activity. In contrast, relatively weak DPPH radical scavenging activity, besides sample 2, was observed for BB samples 5 and 1 . In the $\mathrm{ABTS}^{\bullet+}$ assay, the $\mathrm{IC}_{50}$ values ranged from 0.38 (sample 18) to $1.80 \mathrm{mg} / \mathrm{mL}$ (sample 2). Apart from BB sample 18, a strong $\mathrm{ABTS}^{\bullet+}$ radical scavenging activity was also exhibited by BB samples $9,6,10$, and 11 . In contrast, weak $\mathrm{ABTS}^{\bullet+}$ radical scavenging activity was exhibited by BB samples 2, 5, and 13 .

Table 1. TPC, TFC, DPPH, and ABTS ${ }^{\bullet+}$ of bee bread samples.

\begin{tabular}{ccccc}
\hline $\begin{array}{c}\text { Bee Bread } \\
\text { Samples }\end{array}$ & TPC $^{\mathbf{a}}$ & TFC $^{\mathbf{b}}$ & DPPH $^{\mathbf{c}}$ & ABTS $^{\bullet+\mathbf{d}}$ \\
\hline 1 & $9.56 \pm 0.02$. & $3.88 \pm 0.12$ & $1.25 \pm 0.04$ & $0.51 \pm 0.01$ \\
2 & $7.78 \pm 0.13$ & $3.78 \pm 0.04$ & $1.8 \pm 0.07$ & $1.80 \pm 0.12$ \\
3 & $11.88 \pm 0.06$ & $5.49 \pm 0.02$ & $0.47 \pm 0.03$ & $0.55 \pm 0.02$ \\
4 & $8.34 \pm 0.13$ & $5.02 \pm 0.20$ & $0.53 \pm 0.03$ & $0.53 \pm 0.03$ \\
5 & $7.10 \pm 0.08$ & $3.61 \pm 0.21$ & $1.05 \pm 0.09$ & $1.50 \pm 0.07$ \\
6 & $9.02 \pm 0.08$ & $4.60 \pm 0.00$ & $0.45 \pm 0.03$ & $0.50 \pm 0.01$ \\
7 & $14.26 \pm 0.31$ & $4.82 \pm 0.07$ & $0.46 \pm 0.08$ & $0.60 \pm 0.04$ \\
8 & $10.69 \pm 0.08$ & $4.62 \pm 0.02$ & $0.70 \pm 0.09$ & $0.80 \pm 0.03$ \\
9 & $8.66 \pm 0.26$ & $3.63 \pm 0.09$ & $0.41 \pm 0.04$ & $0.45 \pm 0.02$ \\
10 & $10.17 \pm 0.01$ & $2.56 \pm 0.05$ & $0.61 \pm 0.02$ & $0.50 \pm 0.05$ \\
11 & $13.40 \pm 0.43$ & $5.27 \pm 0.00$ & $0.57 \pm 0.05$ & $0.51 \pm 0.01$ \\
12 & $6.49 \pm 0.04$ & $3.54 \pm 0.02$ & $0.75 \pm 0.05$ & $0.81 \pm 0.04$ \\
13 & $6.63 \pm 0.05$ & $3.31 \pm 0.08$ & $0.70 \pm 0.05$ & $1.02 \pm 0.10$ \\
14 & $11.56 \pm 0.03$ & $4.75 \pm 0.15$ & $0.61 \pm 0.08$ & $0.62 \pm 0.04$ \\
15 & $8.30 \pm 0.13$ & $2.34 \pm 0.22$ & $0.72 \pm 0.03$ & $0.72 \pm 0.03$ \\
16 & $9.87 \pm 0.07$ & $3.18 \pm 0.05$ & $0.57 \pm 0.05$ & $0.63 \pm 0.06$ \\
17 & $11.90 \pm 0.03$ & $3.92 \pm 0.28$ & $0.56 \pm 0.09$ & $0.62 \pm 0.04$ \\
18 & $14.64 \pm 0.26$ & $4.18 \pm 0.03$ & $0.18 \pm 0.02$ & $0.38 \pm 0.05$ \\
\hline
\end{tabular}

a TPC is expressed as mg of gallic acid equivalents-GAEs/g sample; ${ }^{b}$ TFC is expressed as $\mathrm{mg}$ of quercetin equivalent- $\mathrm{QE} / \mathrm{g}$ sample; ${ }^{\mathrm{C}} \mathrm{IC}_{50}$ values of $\mathrm{BB}$ samples in DPPH assay; ${ }^{d} \mathrm{IC}_{50}$ values of BB samples in $\mathrm{ABTS}^{\bullet+}$ assay. All measurements were performed in triplicates and they are expressed as the mean values \pm standard deviation (SD). Values are expressed on fresh weight basis. 


\subsection{Total Phenolic (TPC) and Total Flavonoid Content (TFC)}

In Table 1, the total phenolic content (TPC) and the total flavonoid content (TFC) are presented. The TPC of BB samples, as measured by the Folin-Ciocalteu method, ranged from 6.49 (sample 12) to $14.64 \mathrm{mg}$ (GAEs)/g sample (sample 18). BB samples $(3,7,11$, and 17) also exhibited high TPC (Table 1). The TFC of the tested samples, as measured by the aluminum chloride colorimetric method, ranged from 2.56 (sample 10) to $5.49 \mathrm{mg}$ (QE)/g sample.

\subsection{Antimicrobial Activity}

Eighteen BB samples were tested against clinical and food-borne pathogens. All BB samples exerted bacteriostatic activity against all tested pathogens. Moreover, all samples exerted bactericidal activity, except sample 1, against Salmonella typhimurium, and samples 1, 6, 16, 17, and 18 against Klebsiella pneumoniae (Table 2).

Table 2. MIC and MBC values expressed in $\mathrm{mg} / \mathrm{mL}$.

\begin{tabular}{ccccccccc}
\hline \multirow{2}{*}{ Sample } & \multicolumn{2}{c}{ S. aureus } & \multicolumn{2}{c}{ P. aeruginosa } & \multicolumn{2}{c}{ S. typhimurium } & \multicolumn{2}{c}{ K. pneumoniae } \\
\cline { 2 - 8 } & MIC & MBC & MIC & MBC & MIC & MBC & MIC & MBC \\
\hline 1 & 22.6 & 45.2 & 45.2 & 45.2 & 90.4 & $>90.4$ & 90.4 & $>90.4$ \\
2 & 22.6 & 45.2 & 22.6 & 22.6 & 22.6 & 45.2 & 11.3 & 22.6 \\
3 & 48 & 48 & 24 & 24 & 12 & 24 & 24 & 24 \\
4 & 9.9 & 19.8 & 19.8 & 19.8 & 9.9 & 9.9 & 9.9 & 9.9 \\
5 & 23.5 & 23.5 & 23.5 & 23.5 & 23.5 & 23.5 & 23.5 & 23.5 \\
6 & 45.6 & 45.6 & 45.6 & 45.6 & 45.6 & 91.2 & 45.6 & $>91.2$ \\
7 & 10.4 & 20.8 & 41.6 & 41.6 & 20.8 & 20.8 & 20.8 & 41.6 \\
8 & 21.9 & 21.9 & 43.8 & 43.8 & 21.9 & 21.9 & 43.8 & 43.8 \\
9 & 4.4 & 4.4 & 17.6 & 35.2 & 8.8 & 8.8 & 17.6 & 17.6 \\
10 & 9.4 & 9.4 & 18.8 & 18.8 & 9.4 & 9.4 & 37.6 & 75.2 \\
11 & 10.2 & 10.2 & 40.8 & 40.8 & 40.8 & 40.8 & 40.8 & 40.8 \\
12 & 5 & 5 & 40 & 40 & 10 & 10 & 40 & 40 \\
13 & 4.1 & 4.1 & 65.6 & 65.6 & 16.4 & 16.4 & 32.8 & 32.8 \\
14 & 3.9 & 3.9 & 15.6 & 15.6 & 7.8 & 7.8 & 15.6 & 15.6 \\
15 & 5.2 & 5.2 & 20.8 & 20.8 & 20.8 & 41.6 & 20.8 & 20.8 \\
16 & 11.3 & 11.3 & 22.6 & 22.6 & 45.2 & 90.4 & 45.2 & $>90.4$ \\
17 & 23.3 & 23.3 & 46.6 & 46.6 & 46.6 & 93.2 & 46.6 & $>93.2$ \\
18 & 11 & 11 & 22 & 44 & 22 & 88 & 44 & $>88$ \\
\hline
\end{tabular}

MIC: minimum inhibitory concentration, MBC: minimum bactericidal concentration. Values are expressed on dry weight basis.

The MIC and MBC values of each sample were identical in 14 out of 18 samples tested against methicillin-resistant $S$. aureus (MRSA), in 16 out of 18 tested against $P$. aeruginosa, in 10 out of 18 tested against $S$. typhimurium, and in 10 out of 18 tested against K. pneumoniae. These findings suggest that the antibacterial activity of bee bread is probably due to compounds that cause irreversible damage to bacterial cells. However, the existence of bacteriostatic substances cannot be ruled out.

Eleven out of 18 samples exhibited lower MIC values against $S$. aureus compared to Gram(-) bacteria. In accordance with this observation, the lowest MIC value was recorded against $S$. aureus (sample 14). Of all samples, sample 14 demonstrated the lowest MIC and MBC values against S. aureus $(3.9 \mathrm{mg} / \mathrm{mL})$, P. aeruginosa $(15.6 \mathrm{mg} / \mathrm{mL})$, and S. typhimurium $(7.8 \mathrm{mg} / \mathrm{mL})$. Sample 4 showed the lowest MIC and MBC values $(9.9 \mathrm{mg} / \mathrm{mL})$ against K. pneumoniae compared to the other samples.

Interestingly, there are samples that exhibited lower MIC values against Gram(-) bacteria compared to Gram(+). For instance, sample 3 showed higher MIC and MBC values against $S$. aureus ( $48 \mathrm{mg} / \mathrm{mL}$ in both cases) compared to the corresponding values against other bacteria $(24 \mathrm{mg} / \mathrm{mL}$ against $P$. aeruginosa, and $12 \mathrm{mg} / \mathrm{mL}$ and $24 \mathrm{mg} / \mathrm{mL}$ against S. typhimurium and K. pneumonia, respectively). Interestingly, sample 5 showed identical $\mathrm{MIC}$ and $\mathrm{MBC}$ values against all pathogens $(23.5 \mathrm{mg} / \mathrm{mL})$. 


\subsection{Statistical Analysis}

Statistical analysis was performed aiming to correlate TPC, TFC, and values obtained by DPPH and $\mathrm{ABTS}^{\bullet+}$ assays. The analysis determined a significant strong correlation $(\mathrm{r}=0.719 ; p<0.01)$ between DPPH and $\mathrm{ABTS}^{\bullet+}$ radical scavenging assays (Table 3$)$. The analysis also revealed that there was a moderate though significant correlation among the TPC and TFC values $(r=0.583 ; p<0.05)$ and a moderate though significant negative correlation between the TPC and DPPH or ABTS ${ }^{\bullet+}$ assays $(r=-0.586$ and $r=-0.512$, respectively; $p<0.05$ ) (Table 3). Although a significant correlation between the TFC values and free radical scavenging assays was not revealed (Table 3), when looking at TFC and $\mathrm{DPPH}$ or $\mathrm{ABTS}^{\bullet+}$ values of each BB sample separately, it was observed that some BB samples (e.g., 3, 4, and 11) with high TFC demonstrated high antioxidant activity as well (Table 1).

Table 3. Correlation coefficient $(\mathrm{r})$ values estimated from correlation analysis between values of TPC, TFC, DPPH, and $\mathrm{ABTS}^{\bullet+}$ of bee bread samples.

\begin{tabular}{ccccc}
\hline Methods & TPC & TFC & DPPH & ABTS $^{\bullet+}$ \\
\hline TPC & & $0.583^{*}$ & $-0.586^{*}$ & $-0.512^{*}$ \\
TFC & & -0.444 & -0.249 \\
DPPH & & & & $0.719^{* *}$ \\
\hline
\end{tabular}

* Correlation is statistically significant at $p<0.05 ;{ }^{* *}$ Correlation is statistically significant at $p<0.01$.

Similarly, statistical analysis was performed in order to assess a possible correlation between TPC, TFC, DPPH, and ABTS ${ }^{\bullet+}$ radical scavenging activity as well as MIC and MBC values against the four tested pathogens. The analysis revealed no significant correlation between the above-mentioned values regarding all samples and tested microorganisms. However, a weak positive correlation was revealed between the phenolic or flavonoid content and the MIC and MBC values for S. aureus and P. aeruginosa (Table 4).

Table 4. Correlation coefficient (r) values estimated from correlation analysis of TPC, TFC, DPPH, and $\mathrm{ABTS}^{\bullet+}$ values with MIC and MBC values against four pathogens.

\begin{tabular}{ccccccccc}
\hline & \multicolumn{2}{c}{ S. aureus } & \multicolumn{2}{c}{ P. aeruginosa } & \multicolumn{2}{c}{ S. typhymurium } & \multicolumn{2}{c}{ K. pneumoniae } \\
\hline & MIC & MBC & MIC & MBC & MIC & MBC & MIC & MBC \\
\hline TPC & 0.211 & 0.149 & 0.196 & 0.348 & 0.180 & -0.011 & 0.325 & 0.203 \\
TFC & 0.291 & 0.363 & 0.255 & 0.240 & 0.001 & 0.081 & -0.112 & 0.084 \\
DPPH & -0.033 & 0.013 & 0.057 & -0.279 & 0.000 & 0.192 & -0.224 & 0.049 \\
ABTS $^{\bullet+}$ & 0.009 & 0.008 & 0.122 & -0.249 & 0.156 & 0.229 & -0.179 & 0.175 \\
\hline
\end{tabular}

Finally, statistical analysis was performed in order to assess the correlation among the TPC, TFC, free radical scavenging, and antimicrobial values and the major pollen families present in each BB sample (Table S1). Only the dominant (>10\%) pollen families were included. Moreover, pollen families that were present in less than three samples were excluded from further analysis.

Correlation analysis revealed a significant strong correlation $(\mathrm{r}=1.0 ; p<0.01)$ between TPC and BB content of the Fagaceae pollen family. Regarding TFC values, no significant positive correlation was observed, though a significant negative correlation $(\mathrm{r}=-1.0$; $p<0.01$ ) was revealed between TFC values and Ericaceae pollen content in BB samples. Regarding the free radical scavenging ability, a strong correlation was revealed between Ericaceae and Fagaceae pollen content and DPPH values $(\mathrm{r}=-1.0 ; p<0.01)$ as well as between Rosaceae pollen content and $\mathrm{ABTS}^{\bullet+}$ values $(\mathrm{r}=-1.0 ; p<0.01)$.

Regarding the antimicrobial activity of $\mathrm{BB}$ samples, a negative strong correlation between S. aureus MIC and MBC values and Brassicaceae pollen content was observed $(\mathrm{r}=0.90 ; p=0.01)$. Ericaceae pollen content was negatively correlated $(\mathrm{r}=-1.0 ; p<0.01)$ with $P$. aeruginosa MIC and MBC values. Moreover, Fabaceae pollen content correlated negatively $(\mathrm{r}=0.893 ; p<0.01)$ with $P$. aeruginosa MIC values. Finally, $\mathrm{t}$ strong negative 
correlation $(\mathrm{r}=-0.857 ; p<0.05)$ was observed between Fabaceae pollen content and S. typhimurium MIC values (Table 5).

Table 5. Correlation coefficient ( $r$ ) values estimated from correlation analysis of TPC, TFC, antioxidant activity, and antimicrobial activity values against dominant families of pollen content in each sample.

\begin{tabular}{|c|c|c|c|c|c|c|c|c|c|c|c|c|}
\hline \multirow{2}{*}{$\begin{array}{l}\text { Pollen } \\
\text { Family }\end{array}$} & \multirow{2}{*}{ TPC } & \multirow{2}{*}{ TFC } & \multirow{2}{*}{ DPPH } & \multirow{2}{*}{ ABTS } & \multicolumn{2}{|c|}{ S. aureus } & \multicolumn{2}{|c|}{ P. aeruginosa } & \multicolumn{2}{|c|}{ S. typhimurium } & \multicolumn{2}{|c|}{ K. pneumoniae } \\
\hline & & & & & MIC & MBC & MIC & MBC & MIC & MBC & MIC & MBC \\
\hline Boraginaceae & 0.500 & 0.500 & 0.000 & -0.500 & -0.500 & -0.500 & 0.500 & 0.500 & -0.500 & & -0.500 & \\
\hline Brassicaceae & -0.300 & -0.200 & 0.800 & 0.500 & $-\underset{*}{0.900}$ & $-\underset{*}{0.900}$ & -0.100 & -0.100 & -0.100 & -0.500 & -0.100 & 0.500 \\
\hline $\begin{array}{l}\text { Cistaceae } \\
\text { Ericaceae }\end{array}$ & $\begin{array}{c}-0.600 \\
0.500\end{array}$ & $\begin{array}{l}-0.800 \\
-1.000\end{array}$ & $\begin{array}{c}0.800 \\
-1.000\end{array}$ & $\begin{array}{c}1.000 * * \\
-0.500\end{array}$ & $\begin{array}{c}0.000 \\
-0.500\end{array}$ & $\begin{array}{c}0.000 \\
-0.500\end{array}$ & $\begin{array}{c}0.800 \\
-1.000\end{array}$ & $\begin{array}{c}0.800 \\
-1.000\end{array}$ & $\begin{array}{c}0.800 \\
-\end{array}$ & 0.800 & 0.600 & 0.600 \\
\hline Fabaceae & -0.071 & -0.321 & 0.000 & -0.450 & -0.536 & -0.607 & -0.893 & -0.536 & -0.857 & -0.679 & -0.393 & -0.300 \\
\hline Fagaceae & 1.000 ** & 0.000 & -1.000 & -0.949 & 0.400 & 0.200 & 0.200 & 0.400 & 0.400 & 0.400 & 0.400 & - \\
\hline $\begin{array}{l}\text { Guttiferae } \\
\text { Rosaceae }\end{array}$ & $\begin{array}{l}-0.300 \\
-0.800\end{array}$ & $\begin{array}{c}-0.100 \\
0.000\end{array}$ & $\begin{array}{l}0.500 \\
0.200\end{array}$ & $\begin{array}{c}0.300 \\
-1.000 \\
* *\end{array}$ & $\begin{array}{c}-0.200 \\
0.200\end{array}$ & $\begin{array}{c}-0.200 \\
0.400\end{array}$ & $\begin{array}{c}-0.300 \\
0.200\end{array}$ & $\begin{array}{c}-0.400 \\
0.200\end{array}$ & $\begin{array}{l}-0.300 \\
-0.500\end{array}$ & $\begin{array}{l}-0.100 \\
-0.500\end{array}$ & $\begin{array}{l}-0.100 \\
-0.500\end{array}$ & $\begin{array}{c}-0.800 \\
-\end{array}$ \\
\hline
\end{tabular}

${ }^{*}$ Correlation is statistically significant at $p<0.05 ;{ }^{* *}$ correlation is statistically significant at $p<0.01$.

\subsection{Machine Learning Analysis}

Firstly, we assessed whether the palynological composition could be used to predict any of the antioxidant properties of the samples. Towards this goal, feature selection and linear regression were implemented for all palynological features against each of the four antioxidant-related features (TPC, TFC, DPPH, ABTS) separately. After applying our stringent criteria (see Materials and Methods, Section 4.11), we observed that palynological features could be used to predict the TPC and ABTS values of the samples with R values of 0.85 and 0.89 , respectively, based on five-fold cross-validation. The prediction of the linear regression models is depicted in Figure 1. Of note, random forest models also achieved very good performance for the same feature subsets that were used for linear regression for TPC and ABTS (R values of 0.75 and 0.8 , respectively). Thus, although the number of samples used in our analyses is considered relatively small for such machine learning analyses, still, there seems to be enough information in the palynological composition to allow for relatively accurate prediction of TPC and ABTS activity. We consider these results as very promising, but they will need to be further validated in the future by a larger number of samples.

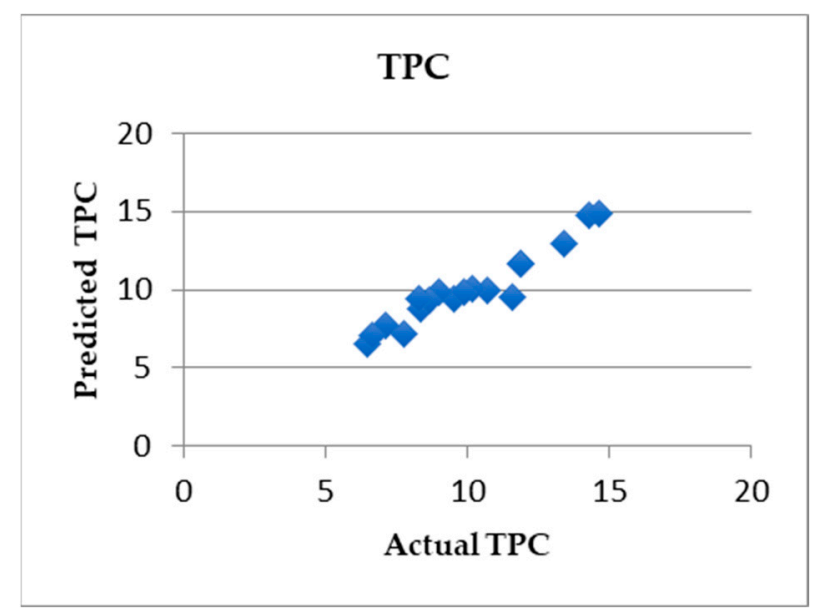

(a)

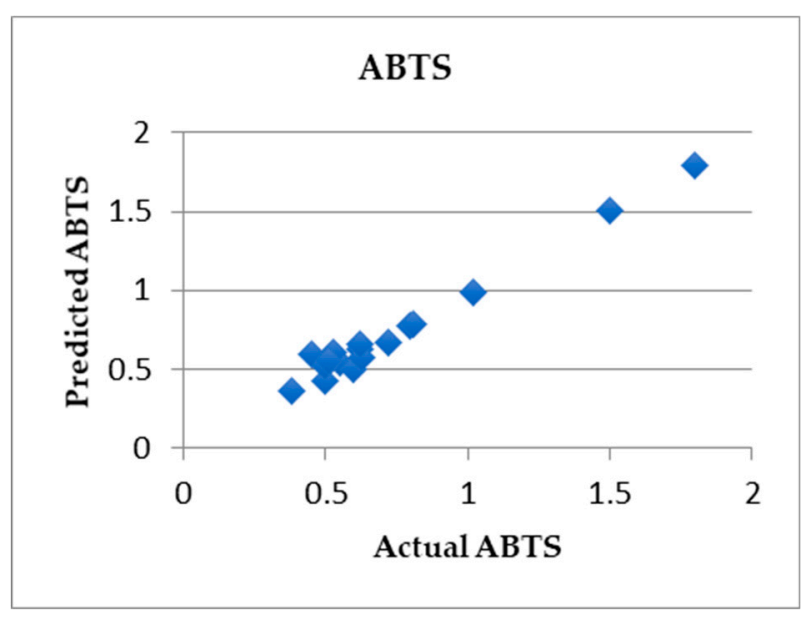

(b)

Figure 1. Predicted (based on linear regression) vs. actual values of TPC (a) and ABTS (b) activity of the samples.

We repeated the machine learning analyses in order to investigate whether we could accurately predict any of the antimicrobial activities (MIC, MBC) of the samples against 
any of the four bacteria or their average activities by using the palynological composition and/or antioxidant activity features. However, none of the models passed all three of our stringent criteria (see Materials and Methods, Section 4.11). Nevertheless, this may be attributed to the rather small number of samples for such computational analyses and it is possible that a future machine learning analysis with more samples may actually reveal palynological features that can accurately predict certain antimicrobial activities.

\section{Discussion}

Bee bread is the least studied bee product regarding its biological properties and rather unknown to most consumers. Relevant studies are scarce, demonstrating high variability of antimicrobial and antioxidant properties [1]. Nevertheless, previous studies conclude that BB should be considered a functional food [2,48,60-62]. The variability of biological properties could be attributed to differences in the botanical and geographical origin of the samples as well as to differences regarding the extraction methods used. Another possible explanation could be that most published studies on BB antimicrobial activity test but few samples (1-5) [1] with the notable exception of the very recent study by Pelka et al. [49] on Polish BB. In order to correlate biological properties with botanical origin, a sufficient number of samples is required to represent both botanical diversity and geographical distribution.

In this study, the first to assess the bioactivity of Greek bee bread, sampling was carefully planned in order to include locations characterized by diverse climate and plant diversity (Figure 2), such as northeastern Crete, where the climate is dry and phryganic ecosystems are dominant, and Kozani and Arta, where the climate is humid and rather cold. Climate differences significantly affect the plant communities from which the bees collect pollen $[63,64]$.

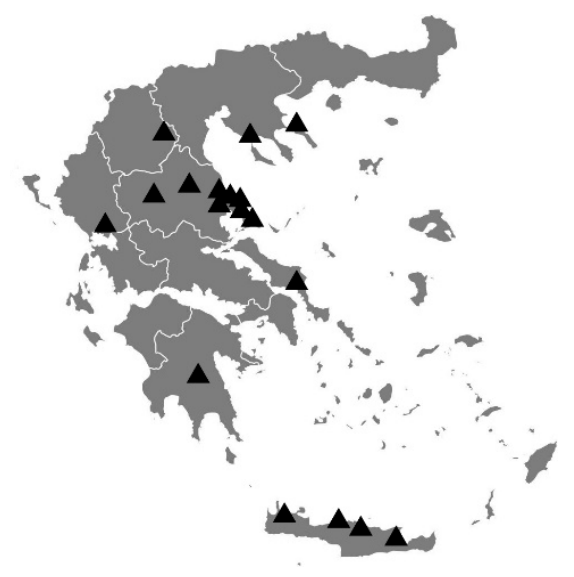

Figure 2. Geographic locations of bee bread samples.

Overall, bee bread has demonstrated high antioxidant activity in previous studies $[2,3,48,61,62,65]$. Our data demonstrated that Greek bee bread samples exert significant antioxidant activity. Sample 18, a monofloral sample of chestnut bee bread (99.8\% Castanea sativa from Mount Athos), exhibited the highest antioxidant activity amongst all samples. This is the first time that a monofloral sample of chestnut bee bread was assessed for its biological properties. In DPPH and $\mathrm{ABTS}^{\bullet+}$ assays, the $\mathrm{IC}_{50}$ values of sample 18 were $0.18 \mathrm{mg} / \mathrm{gr}$ and $0.38 \mathrm{mg} / \mathrm{gr}$, respectively. These values rank it among the most powerful antioxidant foods [66]. This is probably associated with the high content of chestnut pollen in phenols, flavonoids, and kynurenic acid, which exert high antioxidant activity $[67,68]$. Similarly, 16 out of the 18 samples showed IC $_{50}$ values of less than $1 \mathrm{mg} / \mathrm{gr}$ in DPPH and/or ABTS $^{\bullet+}$ assays. Samples 2 and 5 showed values close to or slightly above $1 \mathrm{mg} / \mathrm{gr}$ in both methods. These results suggest that Greek bee bread could be considered a functional food showing significant antioxidant activity. 
It is unknown to what extent the storage conditions of bee bread as well as maturity at the collection time affect its biological properties. Samples 2 and 5 demonstrated the lowest antioxidant activity among the 18 samples. These two samples were stored and collected in a different way than the other samples. Sample 2 was stored for six months before collection, at room temperature inside its comb, which was placed inside an empty hive. In contrast with the other samples, which were collected from frames of mature $\mathrm{BB}$, sample 5 was collected just 11 days after insertion of an empty comb into the hive, presumably long before reaching maturation.

Further research is needed on bee bread post-harvest storage conditions as well as its level of maturity in order to preserve and enhance its biological properties. A recent in vitro study showed that during pollen fermentation under laboratory conditions, there is an increase in phenolic acids, flavonoids, and the antioxidant activity in the fermented product compared to fresh pollen [43]. Therefore, it should be investigated whether this is the case during the conversion of pollen into bee bread in the hive and to what extent the microbiome plays a role in the biological properties of BB. It is plausible that correlation between phenol/flavonoid content and the antibacterial activity of BB was not determined due to different levels of maturity and microbiota contribution in the antimicrobial activity of BB samples. However, other BB compounds than phenols and flavonoids may play a significant role in antimicrobial activity.

Nevertheless, the antioxidant activity of Greek bee bread is statistically correlated to the total content of polyphenols (Table 3). Sample 18, which exhibited the highest antioxidant activity, showed the highest content of polyphenols (Table 1) at the same time.

The antimicrobial activity of Greek bee bread was demonstrated against a food-borne pathogen such as $S$. typhimurium, two important nosocomial pathogens (P. aeruginosa and K. pneumoniae), and against methicillin-resistant $S$. aureus, which, apart from being a cause of serious infections, is also considered a personal hygiene microbiological indicator in food processing, according to EU legislation (Commission Regulation EC 2073/2005). A heat-resistant enterotoxin is produced by $S$. aureus when it forms colonies, and therefore might often be implicated in food poisoning [69,70]. Moreover, P. aeruginosa is also a safety indicator in risk assessment of drinking water, as well as cosmetics and edible pharmaceuticals [71].

All samples demonstrated bacteriostatic activity against all tested pathogens. In most cases the MIC and MBC values were identical, indicating that bee bread exerts mainly bactericidal activity against certain pathogens. BB antimicrobial activity is dose-dependent and variable. In general, S. aureus was the most susceptible tested pathogen. However, there were samples, such as sample 3, that showed higher activity against pathogens other than $S$. aureus or demonstrated the same antibacterial activity regardless of the tested pathogen, as was the case of sample 5 .

The antimicrobial activity of bee bread was generally attributed to diverse phytochemicals, mainly polyphenols, fatty acids, phytosterols, and presumably microbial metabolites [1]. Pelka et al. [49] reported no correlation between the phenolic content and antimicrobial activity of Polish BB. In accordance, this study does not report a statistically significant correlation between antibacterial and antioxidant activity or the total content of phytochemicals such as polyphenols or flavonoids (Table 4). However, it is plausible that specific phytochemicals contribute to the bacteriostatic or bactericidal activity exerted by BB. This may include microbial metabolites such as organic acids, fatty acids, or polysaccharides present in bee bread, and future research should attempt to identify such compounds.

In addition to phytochemicals, other substances such as proteins or proteinaceous compounds present in BB exert antimicrobial activity (Didaras and Mossialos unpublished data). Identification and quantification of proteinaceous compounds that contribute to $\mathrm{BB}$ antimicrobial activity are crucial for understanding BB's mode of action.

Water suspensions of bee bread samples not subjected to physical or chemical processing was tested in order to assess the antioxidant and antimicrobial properties. These 
data are useful for the assessment of the bioavailability of BB compounds, considering that humans cannot effectively digest pollen grains. In addition, they might be applied in BB food-safety risk assessment and BB classification as a functional food because they demonstrate antioxidant and antibacterial activity without any additional processing.

Palynological analysis (Table S1) revealed a complex botanical origin of the BB samples tested in this study. Furthermore, the botanical source of BB samples was statistically correlated with exerted bioactivity for the first time (Table 5). A significant correlation was revealed among Ericaceae and Fagaceae pollen content and DPPH values, as well as Rosaceae pollen content and ABTS values. A strong correlation between MIC and MBC values against $S$. aureus and Brassicaceae pollen content was observed (-0.9). Greece accommodates more than 350 species from the Brassicaceae family. This family, also known as the mustard family, includes plants used in traditional medicine such as Capsella bursa pastoris [72], Sinapis nigra, and Sinapis alba [73], along with common but also healthy foods such as cabbage, broccoli, and cauliflower. Brassicaceae and Sinapis spp. contain glucosinolates that exert anti-tumor and antimicrobial activity [74-76]. They also contain polyphenols, flavonoids, saponines, and triterpens [77]. Ericaceae pollen content significantly correlated with MIC and MBC values against P. aeruginosa. In Greece, bees forage mostly on Erica arborea, Erica manipuliflora, and Arbutus unendo. These plants contain tannins, alkaloids, arbutin, carotenes, flavonoids, organic acids, and saponins [78]. Fabaceae pollen content correlates solely with MIC values against $P$. aeruginosa. In addition, significant correlation was observed between Fabaceae pollen content and S. typhimurium MIC values. The Fabaceae family includes many bee foraging plants such as Spartium junceum, Robinia pseudacacia, Glycyrrhiza glabra, and Ceratonia siliqua.

The identified botanical diversity of BB might also explain the variable antimicrobial activity against specific pathogens exerted by some BB samples. Overall, in-depth study of the chemical composition and the factors that might affect its composition and bioactivity (e.g., botanological or geographical origin, fermentation-maturation process), as well as the mode of action, can lead to diverse BB applications in food preservation, cosmetics, and nutraceuticals.

Conclusively, water suspension of BB exerted significant antioxidant and antimicrobial properties. All samples demonstrated antibacterial activity against all four tested pathogens and our data suggest that BB exerts mainly bactericidal activity. The botanical source of BB samples was statistically correlated with bioactivity for the first time. Botanical diversity of BB might explain the variable antimicrobial activity against specific pathogens. This is the first study to assess the antioxidant and antimicrobial nature of Greek bee bread, which can be considered a functional food and a possible source of bioactive compounds that could be used in food preservation, cosmetics, and nutraceuticals.

\section{Materials and Methods}

\subsection{Bee Bread Samples}

A total of 18 BB samples, harvested from diverse locations in Greece, were provided by individual beekeepers. Seventeen samples were harvested during the 2019 beekeeping period. Sample 2 was collected a year earlier (2018), and the frame was stored in an empty hive, at room temperature, until it was extracted along with the other samples harvested in 2019. Sample 5 was collected from the hive in the fall of 2019, during the flowering of ivy (Hedera helix). An empty frame was inserted in a beehive and bee bread was extracted 11 days after its insertion, and fresh pollen was constantly brought in and stored.

Each sample was assigned a unique reference number and details regarding the geographical location, the possible botanical sources, and the date of harvest were also recorded (Table S1 and Figure 2). BB was sampled directly from the honeycombs using plastic tubes equal in diameter to the honeycomb cells and then each sample was removed from the tube using a plunger. All samples were stored in sterile plastic containers at $-20{ }^{\circ} \mathrm{C}$. Preliminary data on the botanical source of each BB sample was provided by 
the beekeepers based on the flora available during the harvest season at the location of the apiary.

\subsection{Palynological Analysis}

Palynological analysis was conducted by CheMa laboratories (Korinthos, Greece) as follows: A quantity of 5-10 $\mathrm{mg}$ of each sample was dispersed in $1 \mathrm{~mL}$ of deionized water using a vortex mixer. A total of $0.5 \mathrm{~mL}$ of each suspension was spread on a $22 \times 22 \mathrm{~mm}$ area of a microscopy slide and was left to dry at $39{ }^{\circ} \mathrm{C}$. After preheating a cover plate on the hotplate at the same temperature, a drop of glycerol gelatin was transferred to it. This held the pollen in position while the cover glass was lowered onto the dried sediment. The pollen grains were identified using an Euromex BioBlue optical microscope at $400 \times$ magnification. For the identification of the pollens, the following databases were used: Pollen Atlas (available at pollenatlas.net), pollen Wiki database, and the pollen library at the CheMa laboratories.

\subsection{Assessment of the Total Phenolic Content (TPC)}

TPC of the BB samples was determined in accordance with a modified protocol of the Folin-Ciocalteu method [79]. Initially, a quantity $(0.02 \mathrm{~g})$ of each BB sample was weighed and diluted in $1 \mathrm{~mL}$ distilled water. Afterwards, $20 \mu \mathrm{L}$ of each BB sample was added to a tube containing $1 \mathrm{~mL}$ of deionized water. Subsequently, $100 \mu \mathrm{L}$ of Folin-Ciocalteu reagent were added to the mixture, and the tube was allowed to stand at room temperature for $3 \mathrm{~min}$. Thereafter, $280 \mu \mathrm{L}$ of $25 \% w / v$ sodium carbonate solution and $600 \mu \mathrm{L}$ of deionized water were added to the mixture. Following $1 \mathrm{~h}$ of incubation at room temperature in the dark, the absorbance was measured at $765 \mathrm{~nm}$ versus a blank containing Folin-Ciocalteu reagent and deionized water only. The optical density of each sample $(20 \mu \mathrm{L})$ in $25 \% w / v$ solution of sodium carbonate $(280 \mu \mathrm{L})$ and distilled water $(1.7 \mathrm{~mL})$ at $765 \mathrm{~nm}$ was also measured. Measurements were conducted on a Spectro UV-12, MRC, Holon, Israel spectrophotometer. TPC was determined using a standard curve with variable concentrations $(25-500 \mu \mathrm{g} / \mathrm{mL})$ of gallic acid. The results are expressed as mg gallic acid equivalents (GAEs)/g sample using the standard curve (absorbance versus concentration) prepared from authentic gallic acid. The experiments were carried out in triplicates and at least on 2 separate occasions.

\subsection{Assessment of the Total Flavonoid Content (TFC)}

Total flavonoids were determined by using the aluminum chloride colorimetric method, as described by Hassan et al. [80], with minor modifications. Each sample (0.2 g) was extracted with $5 \mathrm{~mL}$ of $80 \%$ ethanol. The samples were mixed in vortex for approx. $1 \mathrm{~min}$ and left overnight at room temperature. After centrifugation at $4000 \times \mathrm{g}$ for $10 \mathrm{~min}$, the supernatant was collected and filtered with plain filter paper and the transparent filtrates (bee bread extracts) were stored in sealed glass tubes for further analysis.

The total flavonoid content was determined using a standard curve of quercetin concentrations $(5-100 \mu \mathrm{g} / \mathrm{mL})$. For the preparation of the standard curve, $100 \mathrm{mg}$ of quercetin were dissolved in $100 \mathrm{~mL}(1 \mathrm{mg} / \mathrm{mL}=1000 \mu \mathrm{g} / \mathrm{mL})$ of $80 \%$ ethanol and then from this stock solution diluted standard solutions were prepared. From each diluted standard solution, $0.5 \mathrm{~mL}$ was transferred in glass tubes by adding $1.5 \mathrm{~mL}$ of $95 \%$ ethanol, $0.1 \mathrm{~mL}$ of $10 \% \mathrm{AlCl}_{3}, 0.1 \mathrm{~mL}$ of $1 \mathrm{M}$ potassium acetate, and $2.8 \mathrm{~mL}$ of distilled water. For the blank sample, $0.5 \mathrm{~mL}$ of $80 \%$ ethanol was transferred in a glass tube with $1.5 \mathrm{~mL}$ of $95 \%$ ethanol, $0.1 \mathrm{~mL}$ of $1 \mathrm{M}$ potassium acetate, and $2.9 \mathrm{~mL}$ of distilled water (i.e., $0.1 \mathrm{~mL}$ of distilled water was used to replace the $0.1 \mathrm{~mL}$ of $10 \% \mathrm{AlCl}_{3}$ ). Samples were incubated at room temperature for $30 \mathrm{~min}$ before measuring the absorbance of each sample at $415 \mathrm{~nm}$ on an MRC Spectro UV-12 instrument. The same procedure was followed for the measurement of bee bread extracts by replacing the $0.5 \mathrm{~mL}$ of the standard solutions with $0.5 \mathrm{~mL}$ of each sample filtrate after appropriate dilution (1/10 dilution) of the extracts (filtrates) with $80 \%$ ethanol. The results are expressed as mg quercetin equivalent $(\mathrm{QE}) / \mathrm{g} d \mathrm{~d}$ of extract 
using the standard curve (absorbance versus concentration) prepared from quercetin. The experiments were carried out in triplicate.

\subsection{Assessment of Free Radical Scavenging Ability by the Use of the DPPH Radical Assay}

The 2,2-diphenyl-1-picrylhydrazyl (DPPH) radical scavenging activity of the bee bread samples was evaluated as previously described [81]. For assessing DDPH, a quantity (0.2 g) of each BB sample was weighed and diluted in $1 \mathrm{~mL} \mathrm{99.9 \%} \mathrm{methanol.} \mathrm{Briefly,} \mathrm{a}$ $1 \mathrm{~mL}$ freshly prepared methanolic solution of DPPH radical $(100 \mu \mathrm{M})$ was mixed with tested bee bread samples at different concentrations following dilution in methanol. The contents were vigorously mixed, incubated at room temperature in the dark for $20 \mathrm{~min}$, and the absorbance was read at $517 \mathrm{~nm}$. Measurements were conducted on an MRC Spectro UV-12 instrument. In each experiment, the tested sample alone in methanol was used as blank and DPPH radical alone in methanol was used as control. The percentage of radical scavenging capacity (RSC) of the tested samples was calculated according to the following equation: $\operatorname{RSC}(\%)=\left[\left(\mathrm{A}_{\text {control }}-\mathrm{A}_{\text {sample }}\right) / \mathrm{A}_{\text {control }}\right] \times 100$, where $\mathrm{A}_{\text {control }}$ and $\mathrm{A}_{\text {sample }}$ are the absorbance values of the control and the tested samples, respectively. Moreover, in order to compare the radical scavenging efficiency of the samples, the $\mathrm{IC}_{50}$ value showing the concentration that caused 50\% scavenging of DPPH radical was calculated from the graph plotted RSC percentage against sample concentration. All experiments were carried out in triplicate and at least on 2 separate occasions.

\subsection{Assesment of Free Radical Scavenging Ability by the Use of the ABTS ${ }^{\bullet+}$ Radical Cation Assay}

The free radical scavenging activity of the bee bread samples was further determined by $2,2^{\prime}$-azino-bis (3-ethylbenzothiazoline-6-sulphonic acid) (ABTS) radical cation (ABTS ${ }^{\bullet+}$ ) decolorization assay as previously described by Cano et al. [82], with some modifications. For assessing ABTS, a quantity ( $0.2 \mathrm{~g})$ of each BB sample was weighed and diluted in $1 \mathrm{~mL}$ distilled water. Briefly, ABTS $^{\bullet+}$ radical was produced by mixing $2 \mathrm{mM}$ ABTS with $30 \mu \mathrm{M}$ $\mathrm{H}_{2} \mathrm{O}_{2}$ and $6 \mu \mathrm{M}$ horseradish peroxidase (HRP) enzyme in $50 \mathrm{mM}$ PBS (pH 7.5). Immediately following the addition of the HRP enzyme, the contents were vigorously mixed, incubated at room temperature in the dark, and the reaction was monitored at $730 \mathrm{~nm}$ until stable absorbance was obtained. Subsequently, $10 \mu \mathrm{L}$ of different sample concentrations diluted in distilled water were added in the reaction mixture and the decrease in absorbance at $730 \mathrm{~nm}$ was measured. In each experiment, the tested sample alone containing $1 \mathrm{mM}$ ABTS and $30 \mu \mathrm{M} \mathrm{H}_{2} \mathrm{O}_{2}$ in $50 \mathrm{mM}$ PBS (pH 7.5) was used as a blank, whereas the formed ABTS ${ }^{\bullet+}$ radical solution alone with $10 \mu \mathrm{L} \mathrm{H}_{2} \mathrm{O}$ was used as a control. The RSC percentage and the $\mathrm{IC}_{50}$ values were determined as described above for the DPPH method. All experiments were carried out in triplicate and at least on 2 separate occasions.

\subsection{Bacterial Strains and Growth Conditions}

The antibacterial activity of BB samples was tested against methicillin-resistant Staphylococcus aureus strain 1552, carbapenem-resistant Pseudomonas aeruginosa strain 1773, Salmonella typhimurium, and Klebsiella pneumonia. All strains were identified and characterized by standard laboratory methods (kindly provided by Prof. Spyros Pournaras, School of Medicine, National and Kapodistrian University of Athens, Athens, Greece). The bacteria were routinely grown in Mueller-Hinton Broth (Lab M, Bury, UK) or Mueller-Hinton agar (Lab M) at $37^{\circ} \mathrm{C}$.

\subsection{Determination of Minimum Inhibitory Concentration (MIC)}

The minimum inhibitory concentration (MIC) of the BB samples was determined in sterile 96-well polystyrene microtiter plates (Kisker Biotech GmbH \& Co. KG, Steinfurt, Germany) using a spectrophotometric bioassay as previously described [7], with some modifications. Briefly, $0.5 \mathrm{~g}$ BB sample was suspended in sterile $\mathrm{ddH}_{2} \mathrm{O}$ ( $2 \mathrm{~mL}$ final volume) for one hour at room temperature with occasional vortex and then centrifuged at $10,000 \times g$ for $7 \mathrm{~min}$. The aqueous phase filtered through a $0.22 \mu \mathrm{M}$ syringe filter and used for 
serial dilutions in Mueller-Hinton broth corresponding from 25 to $0.39 \% w / v$. Overnight bacterial cultures grown in Mueller-Hinton broth was adjusted to a $0.5 \mathrm{McFarland}$ turbidity standard $\left(\sim 1.5 \times 10^{8} \mathrm{CFU} / \mathrm{mL}\right)$. Ten $\mu \mathrm{L}$ Mueller-Hinton broth containing approximately $5 \times 10^{4}$ CFUs were added to $190 \mu \mathrm{L}$ of tested 2-fold sample dilutions.

Positive control wells containing Mueller-Hinton broth inoculated with bacteria tested the growth of the pathogen. Negative BB control wells contained BB dilutions in MuellerHinton broth without bacteria. Negative Mueller-Hinton control wells containing only Mueller-Hinton broth without bacteria were used to test any possible contamination.

The optical density (OD) was determined at $630 \mathrm{~nm}$ using an EL $\times 808$ absorbance microplate reader (BioTek Instruments, Inc., Winooski, VT, USA) just prior to incubation ( $t=0)$ and $24 \mathrm{~h}$ after incubation $(\mathrm{t}=24)$ at $37^{\circ} \mathrm{C}$. The OD for each negative $\mathrm{BB}$ control replicate well at $t=24$ was subtracted from the OD of the same replicate test well with bacteria at $t=24$. The growth inhibition at each $\mathrm{BB}$ dilution was determined using the formula $\%$ inhibition = $[1-(\mathrm{OD}$ test well-OD of corresponding negative BB control well) $] \times 100$. MIC was determined as the lowest bee bread concentration which results in $100 \%$ growth inhibition.

MIC values were expressed as $\mathrm{mg} / \mathrm{mL}$ on dry weight basis. In order to measure the dry weight, the filtered aqueous phase of corresponding serial dilutions was dried for $24 \mathrm{~h}$ at $90^{\circ} \mathrm{C}$ and then weighed. Drying was performed twice for each sample.

\subsection{Determination of Minimum Bactericidal Concentration (MBC)}

The MBC was determined by transferring a small quantity of sample contained in each replicate well of the microtiter plates to Mueller-Hinton agar plates by using a microplate replicator (BoekelScientific, Feasterville-Trevose, PA, USA). The plates were incubated at $37^{\circ} \mathrm{C}$ for $24 \mathrm{~h}$. The $\mathrm{MBC}$ was determined as the lowest bee bread concentration at which no grown colonies were observed [83].

\subsection{Statistical Analysis}

All results are expressed as the mean $\pm \mathrm{SD}(n=3)$. For statistical analysis, one-way analysis of variance (ANOVA) was applied, followed by Dunnett's test for post-hoc analysis. All correlation analyses were conducted using Spearman's correlation analysis. Values of $p<0.05$ were considered to indicate statistically significant differences. All statistical analyses were performed using the SPSS version 13.0 statistical package (SPSS, Inc., Chicago, IL, USA).

\subsection{Machine Learning Analysis for Prediction of Properties}

A machine learning analysis was performed with the WEKA software in order to determine whether (i) antioxidant activity could be predicted from palynological composition, and (ii) antimicrobial activity could be predicted from palynological composition and/or antioxidant activity. Several linear regression and random forest models were assessed using five-fold cross-validation, after performing feature selection with a wrapper method (within WEKA). In order to further assess the robustness of our conclusions, the feature vectors of the 18 samples were shuffled and underwent feature selection and linear regression analysis to ensure that the high performance of certain models (based on actual data) could not be achieved by chance alone. Specifically, for the machine learning analysis and the sample clustering (see Section 4.12, below), the antimicrobial activity value of each sample was transformed to the dilution that the sample had to undergo, in order to achieve MIC or MBC. Samples with no MIC or MBC values were assigned zero values. A linear regression model was deemed to be predictive if (i) it achieved an $R$ value above 0.5 for a certain combination of features, (ii) if the same combination of features achieved an $\mathrm{R}$ value above 0.5 for the random forest model as well, and (iii) if feature selection and linear regression modeling of the shuffled data could not achieve such high $R$ values. Thus, very stringent criteria were applied. 


\subsection{Clustering of Samples Based on Their Properties}

Clustering of the samples was performed with the pheatmap package in R. For the clustering of the 18 samples based on their palynological composition only, the Euclidean distance metric was applied.

Supplementary Materials: The following are available online at https://www.mdpi.com/article/10 .3390/antibiotics10050555/s1, Table S1: Palynological analysis of bee bread samples.

Author Contributions: N.A.D.: investigation, methodology, data analysis, writing_original draft, review, and editing; I.K.: investigation, writing — original draft, data analysis; T.G.D.: data analysis, writing —original draft, review, and editing; C.M.: investigation, data analysis; K.K.: writing—original draft, review, and editing; I.G.: data analysis, review, and editing; D.S.: methodology, review, and editing; F.H.: review and editing; G.D.A.: methodology, data analysis, writing—original draft, review, and editing; D.M.: conceptualization, methodology, data analysis, writing-original draft, review, and editing, supervision, resources. All authors have read and agreed to the published version of the manuscript.

Funding: No external funding was received. I.K. is the recipient of a postdoctoral fellowship under the emblematic action "Honeybee Road" supported by the General Secretariat for Research and Innovation (G.S.R.I.).

Institutional Review Board Statement: Not applicable.

Informed Consent Statement: Not applicable.

Data Availability Statement: Not applicable.

Acknowledgments: We thank all the individual beekeepers who kindly provided the BB samples.

Conflicts of Interest: The authors declare no conflict of interest.

\section{References}

1. Didaras, N.A.; Karatasou, K.; Dimitriou, T.G.; Amoutzias, G.D.; Mossialos, D. Antimicrobial Activity of Bee-Collected Pollen and Beebread: State of the Art and Future Perspectives. Antibiotics 2020, 9, 811. [CrossRef]

2. Bakour, M.; Fernandes, Â.; Barros, L.; Sokovic, M.; Ferreira, I.C.F.R.; Lyoussi, B. Bee bread as a functional product: Chemical composition and bioactive properties. LWT 2019, 109, 276-282. [CrossRef]

3. Mărgăoan, R.; Stranț, M.; Varadi, A.; Topal, E.; Yücel, B.; Cornea-Cipcigan, M.; Campos, M.G.; Vodnar, D.C. Bee Collected Pollen and Bee Bread: Bioactive Constituents and Health Benefits. Antioxidants 2019, 8, 568. [CrossRef] [PubMed]

4. Bucekova, M.; Bugarova, V.; Godocikova, J.; Majtan, J. Demanding New Honey Qualitative Standard Based on Antibacterial Activity. Foods 2020, 9, 1263. [CrossRef]

5. Godocikova, J.; Bugarova, V.; Kast, C.; Majtan, V.; Majtan, J. Antibacterial potential of Swiss honeys and characterisation of their bee-derived bioactive compounds. J. Sci. Food Agric. 2020, 100, 335-342. [CrossRef]

6. Tsavea, E.; Mossialos, D. Antibacterial activity of honeys produced in Mount Olympus area against nosocomial and foodborne pathogens is mainly attributed to hydrogen peroxide and proteinaceous compounds. J. Apic. Res. 2019, 58, 756-763. [CrossRef]

7. Stagos, D.; Soulitsiotis, N.; Tsadila, C.; Papaeconomou, S.; Arvanitis, C.; Ntontos, A.; Karkanta, F.; Adamou-Androulaki, S.; Petrotos, K.; Spandidos, D.A.; et al. Antibacterial and antioxidant activity of different types of honey derived from Mount Olympus in Greece. Int. J. Mol. Med. 2018, 42, 726-734. [CrossRef]

8. Anand, S.; Deighton, M.; Livanos, G.; Pang, E.C.K.; Mantri, N. Agastache honey has superior antifungal activity in comparison with important commercial honeys. Sci. Rep. 2019, 9, 18197. [CrossRef] [PubMed]

9. Al-Hatamleh, M.A.I.I.; Hatmal, M.M.; Sattar, K.; Ahmad, S.; Mustafa, M.Z.; Bittencourt, M.D.C.; Mohamud, R. Antiviral and Immunomodulatory Effects of Phytochemicals from Honey against COVID-19: Potential Mechanisms of Action and Future Directions. Molecules 2020, 25, 5017. [CrossRef] [PubMed]

10. Watanabe, K.; Rahmasari, R.; Matsunaga, A.; Haruyama, T.; Kobayashi, N. Anti-influenza Viral Effects of Honey In Vitro: Potent High Activity of Manuka Honey. Arch. Med. Res. 2014, 45, 359-365. [CrossRef] [PubMed]

11. Shahzad, A.; Cohrs, R.J. In vitro antiviral activity of honey against varicella zoster virus (VZV): A translational medicine study for potential remedy for shingles. Transl. Biomed. 2012, 3, 2. [CrossRef] [PubMed]

12. Hadagali, M.D.; Chua, L.S. The anti-inflammatory and wound healing properties of honey. Eur. Food Res. Technol. 2014, 239, 1003-1014. [CrossRef]

13. Waheed, M.; Hussain, M.B.; Javed, A.; Mushtaq, Z.; Hassan, S.; Shariati, M.A.; Khan, M.U.; Majeed, M.; Nigam, M.; Mishra, A.P.; et al. Honey and cancer: A mechanistic review. Clin. Nutr. 2019, 38, 2499-2503. [CrossRef] [PubMed]

14. Ahmed, S.; Othman, N.H. The anti-cancer effects of Tualang honey in modulating breast carcinogenesis: An experimental animal study. BMC Complement. Altern. Med. 2017, 17, 208. [CrossRef] [PubMed] 
15. Tsiapara, A.V.; Jaakkola, M.; Chinou, I.; Graikou, K.; Tolonen, T.; Virtanen, V.; Moutsatsou, P. Bioactivity of Greek honey extracts on breast cancer (MCF-7), prostate cancer (PC-3) and endometrial cancer (Ishikawa) cells: Profile analysis of extracts. Food Chem. 2009, 116, 702-708. [CrossRef]

16. Dżugan, M.; Tomczyk, M.; Sowa, P.; Grabek-Lejko, D. Antioxidant Activity as Biomarker of Honey Variety. Molecules 2018, 23, 2069. [CrossRef]

17. Beretta, G.; Orioli, M.; Facino, R.M. Antioxidant and radical scavenging activity of honey in endothelial cell cultures (EA.hy926). Planta Med. 2007, 73, 1182-1189. [CrossRef]

18. Gheldof, N.; Wang, X.H.; Engeseth, N.J. Buckwheat honey increases serum antioxidant capacity in humans. J. Agric. Food Chem. 2003, 51, 1500-1505. [CrossRef]

19. Jan Mei, S.; Mohd Nordin, M.S.; Norrakiah, A.S. Fructooligosaccharides in honey and effects of honey on growth of Bifidobacterium longum BB 536. Int. Food Res. J. 2010, 17, 557-561.

20. Mohan, A.; Quek, S.Y.; Gutierrez-Maddox, N.; Gao, Y.; Shu, Q. Effect of honey in improving the gut microbial balance. Food Qual. Saf. 2017, 1, 107-115. [CrossRef]

21. Gaifullina, L.R.; Saltykova, E.S.; Nikolenko, A.G. Prebiotic and probiotic properties of honey. In Honey: Geographical Origins, Bioactive Properties and Health Benefits; Nova Science Publishers, Inc.: New York, NY, USA, 2016; pp. 53-79. ISBN 9781634854719.

22. Kostić, A.Ž.; Milinčić, D.D.; Barać, M.B.; Ali Shariati, M.; Tešić, Ž.L.; Pešić, M.B. The Application of Pollen as a Functional Food and Feed Ingredient-The Present and Perspectives. Biomolecules 2020, 10, 84. [CrossRef]

23. Li, Q.-Q.; Wang, K.; Marcucci, M.C.; Sawaya, A.C.H.F.; Hu, L.; Xue, X.-F.; Wu, L.-M.; Hu, F.-L. Nutrient-rich bee pollen: A treasure trove of active natural metabolites. J. Funct. Foods 2018, 49, 472-484. [CrossRef]

24. Ares, A.M.; Valverde, S.; Bernal, J.L.; Nozal, M.J.; Bernal, J. Extraction and determination of bioactive compounds from bee pollen. J. Pharm. Biomed. Anal. 2018, 147, 110-124. [CrossRef]

25. Palmer-Young, E.C.; Farrell, I.W.; Adler, L.S.; Milano, N.J.; Egan, P.A.; Irwin, R.E.; Stevenson, P.C. Secondary metabolites from nectar and pollen: A resource for ecological and evolutionary studies. Ecology 2019, 100, e02621. [CrossRef]

26. Paupière, M.J.; Müller, F.; Li, H.; Rieu, I.; Tikunov, Y.M.; Visser, R.G.F.; Bovy, A.G. Untargeted metabolomic analysis of tomato pollen development and heat stress response. Plant Reprod. 2017, 30, 81-94. [CrossRef]

27. Rivest, S.; Forrest, J.R.K. Defence compounds in pollen: Why do they occur and how do they affect the ecology and evolution of bees? New Phytol. 2020, 225, 1053-1064. [CrossRef] [PubMed]

28. Eteraf-Oskouei, T.; Shafiee-Khamneh, A.; Heshmati-Afshar, F.; Delazar, A. Anti-inflammatory and anti-angiogenesis effect of bee pollen methanolic extract using air pouch model of inflammation. Res. Pharm. Sci. 2020, 15, 66. [CrossRef]

29. Komosinska-Vassev, K.; Olczyk, P.; Kaźmierczak, J.; Mencner, L.; Olczyk, K. Bee Pollen: Chemical Composition and Therapeutic Application. Evid.-Based Complement. Altern. Med. 2015, 2015, 297425. [CrossRef] [PubMed]

30. Graikou, K.; Kapeta, S.; Aligiannis, N.; Sotiroudis, G.; Chondrogianni, N.; Gonos, E.; Chinou, I. Chemical analysis of Greek pollen-Antioxidant, antimicrobial and proteasome activation properties. Chem. Cent. J. 2011, 5, 33. [CrossRef]

31. Morais, M.; Moreira, L.; Feás, X.; Estevinho, L.M. Honeybee-collected pollen from five Portuguese Natural Parks: Palynological origin, phenolic content, antioxidant properties and antimicrobial activity. Food Chem. Toxicol. 2011, 49, $1096-1101$. [CrossRef] [PubMed]

32. Fan, T.F.; Park, S.; Shi, Q.; Zhang, X.; Liu, Q.; Song, Y.; Chin, H.; Bin Ibrahim, M.S.; Mokrzecka, N.; Yang, Y.; et al. Transformation of hard pollen into soft matter. Nat. Commun. 2020, 11, 1449. [CrossRef]

33. Amores-Arrocha, A.; Roldán, A.; Jiménez-Cantizano, A.; Caro, I.; Palacios, V. Evaluation of the use of multiflora bee pollen on the volatile compounds and sensorial profile of Palomino fino and Riesling white young wines. Food Res. Int. 2018, 105, 197-209. [CrossRef] [PubMed]

34. Karabagias, I.; Karabagias, V.; Gatzias, I.; Riganakos, K. Bio-Functional Properties of Bee Pollen: The Case of "Bee Pollen Yoghurt". Coatings 2018, 8, 423. [CrossRef]

35. Uțoiu, E.; Matei, F.; Toma, A.; Diguță, C.F.; Ștefan, L.M.; Mănoiu, S.; Vrăjmașu, V.V.; Moraru, I.; Oancea, A.; Israel-Roming, F.; et al. Bee collected pollen with enhanced health benefits, produced by fermentation with a Kombucha Consortium. Nutrients 2018, 10, 1365. [CrossRef]

36. Yerlikaya, O. Effect of bee pollen supplement on antimicrobial, chemical, rheological, sensorial properties and probiotic viability of fermented milk beverages. Mljekarstvo 2014, 64, 268-279. [CrossRef]

37. Roldán, A.; Van Muiswinkel, G.C.J.; Lasanta, C.; Palacios, V.; Caro, I. Influence of pollen addition on mead elaboration: Physicochemical and sensory characteristics. Food Chem. 2011, 126, 574-582. [CrossRef]

38. Brodschneider, R.; Crailsheim, K. Nutrition and health in honey bees. Apidologie 2010, 41, 278-294. [CrossRef]

39. Vásquez, A.; Olofsson, T.C. The lactic acid bacteria involved in the production of bee pollen and bee bread. J. Apic. Res. 2009, 48, 189-195. [CrossRef]

40. Gilliam, M. Identification and roles of non-pathogenic microflora associated with honey bees. FEMS Microbiol. Lett. 1997, 155, 1-10. [CrossRef]

41. Di Cagno, R.; Filannino, P.; Cantatore, V.; Gobbetti, M. Novel solid-state fermentation of bee-collected pollen emulating the natural fermentation process of bee bread. Food Microbiol. 2019, 82, 218-230. [CrossRef]

42. Salazar-González, C.; Díaz-Moreno, C. The nutritional and bioactive aptitude of bee pollen for a solid-state fermentation process. J. Apic. Res. 2016, 55, 161-175. [CrossRef] 
43. Kaškonienè, V.; Adaškevičiūtè, V.; Kaškonas, P.; Mickienè, R.; Maruška, A. Antimicrobial and antioxidant activities of natural and fermented bee pollen. Food Biosci. 2020, 34, 100532. [CrossRef]

44. Dharampal, P.S.; Carlson, C.; Currie, C.R.; Steffan, S.A. Pollen-borne microbes shape bee fitness. Proc. R. Soc. B Biol. Sci. 2019, 286. [CrossRef]

45. Steffan, S.A.; Dharampal, P.S.; Danforth, B.N.; Gaines-Day, H.R.; Takizawa, Y.; Chikaraishi, Y. Omnivory in bees: Elevated trophic positions among all major bee families. Am. Nat. 2019, 194, 414-421. [CrossRef] [PubMed]

46. Kaškoniene, V.; Katilevičiūtè, A.; Kaškonas, P.; Maruška, A. The impact of solid-state fermentation on bee pollen phenolic compounds and radical scavenging capacity. Chem. Pap. 2018, 72, 2115-2120. [CrossRef]

47. Anđelković, B.; Jevtić, G.; Mladenović, M.; Marković, J.; Petrović, M.; Nedić, N. Quality of pollen and honey bee bread collected in spring. J. Hyg. Eng. Des. 2012, 1, 275-277.

48. Kieliszek, M.; Piwowarek, K.; Kot, A.M.; Błażejak, S.; Chlebowska-Śmigiel, A.; Wolska, I. Pollen and bee bread as new healthoriented products: A review. Trends Food Sci. Technol. 2018, 71, 170-180. [CrossRef]

49. Pełka, K.; Otłowska, O.; Worobo, R.W.; Szweda, P. Bee bread exhibits higher antimicrobial potential compared to bee pollen. Antibiotics 2021, 10, 125. [CrossRef]

50. Urcan, A.; Criste, A.; Dezmirean, D.; Bobiș, O.; Mărghitaș, L.; Mărgăoan, R.; Hrinca, A. Antimicrobial Activity of Bee Bread Extracts Against Different Bacterial Strains. Bull. UASVM Anim. Sci. Biotechnol. 2018, 75, 85-91. [CrossRef]

51. Abouda, Z.; Zerdani, I.; Kalalou, I.; Faid, M.; Ahami, M.T. The antibacterial activity of moroccan bee bread and bee-pollen (fresh and dried) against pathogenic bacteria. Res. J. Microbiol. 2011, 6, 376. [CrossRef]

52. Baltrušayt, V.; Venskmonis, P.R.; Čeksteryte, V. Antibacterial activity of honey and beebread of different origin against S. Aureus and S. epidermidis. Food Technol. Biotechnol. 2007, 45, 201-208.

53. Velásquez, P.; Rodríguez, K.; Retamal, M.; Giordano, A.; Valenzuela, L.M.; Montenegro, G. Relation between composition, antioxidant and antibacterial activities and botanical origin of multi-floral bee pollen. J. Appl. Bot. Food Qual. 2017, 90, 306-314. [CrossRef]

54. Mărgăoan, R.; Al Mărghitaş, L.; Dezmirean, D.S.; Dulf, F.V.; Bunea, A.; Socaci, S.A.; Bobiş, O. Predominant and secondary pollen botanical origins influence the carotenoid and fatty acid profile in fresh honeybee-collected pollen. J. Agric. Food Chem. 2014, 62, 6306-6316. [CrossRef]

55. Bucekova, M.; Buriova, M.; Pekarik, L.; Majtan, V.; Majtan, J. Phytochemicals-mediated production of hydrogen peroxide is crucial for high antibacterial activity of honeydew honey. Sci. Rep. 2018, 8, 9061. [CrossRef]

56. Felicioli, A.; Cilia, G.; Mancini, S.; Turchi, B.; Galaverna, G.; Cirlini, M.; Cerri, D.; Fratini, F. In vitro antibacterial activity and volatile characterisation of organic Apis mellifera ligustica (Spinola, 1906) beeswax ethanol extracts. Food Biosci. 2019, 29, 102-109. [CrossRef]

57. Cilia, G.; Fratini, F.; Marchi, M.; Sagona, S.; Turchi, B.; Adamchuk, L.; Felicioli, A.; Kačániová, M. Antibacterial activity of honey samples from Ukraine. Vet. Sci. 2020, 7, 181. [CrossRef] [PubMed]

58. Almasaudi, S.B.; Al-Nahari, A.A.M.; Abd El-Ghany, E.S.M.; Barbour, E.; Al Muhayawi, S.M.; Al-Jaouni, S.; Azhar, E.; Qari, M.; Qari, Y.A.; Harakeh, S. Antimicrobial effect of different types of honey on Staphylococcus aureus. Saudi J. Biol. Sci. 2017, 24, 1255-1261. [CrossRef] [PubMed]

59. Georghiou, K.; Delipetrou, P. Patterns and traits of the endemic plants of Greece. Bot. J. Linn. Soc. 2010, 162, 130-153. [CrossRef]

60. Tomás, A.; Falcão, S.I.; Russo-Almeida, P.; Vilas-Boas, M. Potentialities of beebread as a food supplement and source of nutraceuticals: Botanical origin, nutritional composition and antioxidant activity. J. Apic. Res. 2017, 56, 219-230. [CrossRef]

61. Nagai, T.; Nagashima, T.; Myoda, T.; Inoue, R. Preparation and functional properties of extracts from bee bread. Nahrung/Food 2004, 48, 226-229. [CrossRef]

62. Khalifa, S.A.M.; Elashal, M.; Kieliszek, M.; Ghazala, N.E.; Farag, M.A.; Saeed, A.; Xiao, J.; Zou, X.; Khatib, A.; Göransson, U.; et al. Recent insights into chemical and pharmacological studies of bee bread. Trends Food Sci. Technol. 2020, 97, 300-316. [CrossRef]

63. Azonwade, F.E.; Paraïso, A.; Tossou, M.G.; Sina, H.; Kelomey, A.E.; Chabi-Sika, K.; Baba-Moussa, L. Pollen Analysis of the Honeys Samples Produced in the Three Phyto-geographical Zones of Benin. Eur. Sci. J. 2017, 13, 528. [CrossRef]

64. Harrison, S.; Spasojevic, M.J.; Li, D. Climate and plant community diversity in space and time. Proc. Natl. Acad. Sci. USA 2020, 117, 4464-4470. [CrossRef] [PubMed]

65. Zuluaga, C.M.; Serrato, J.C.; Quicazan, M.C. Bee-pollen structure modification by physical and biotechnological processing: Influence on the availability of nutrients and bioactive compounds. Chem. Eng. Trans. 2015, 43, 79-84. [CrossRef]

66. Sreeramulu, D.; Reddy, C.V.K.; Chauhan, A.; Balakrishna, N.; Raghunath, M. Natural Antioxidant Activity of Commonly Consumed Plant Foods in India: Effect of Domestic Processing. Oxidative Med. Cell. Longev. 2013, 2013, 1-12. [CrossRef] [PubMed]

67. Barreira, J.C.M.; Ferreira, I.C.F.R.; Oliveira, M.B.P.P.; Pereira, J.A. Antioxidant activities of the extracts from chestnut flower, leaf, skins and fruit. Food Chem. 2008, 107, 1106-1113. [CrossRef]

68. Turski, M.P.; Chwil, S.; Turska, M.; Chwil, M.; Kocki, T.; Rajtar, G.; Parada-Turska, J. An exceptionally high content of kynurenic acid in chestnut honey and flowers of chestnut tree. J. Food Compos. Anal. 2016, 48, 67-72. [CrossRef]

69. Fisher, E.L.; Otto, M.; Cheung, G.Y.C. Basis of virulence in enterotoxin-mediated staphylococcal food poisoning. Front. Microbiol. 2018, 9, 436. [CrossRef]

70. Schelin, J.; Wallin-Carlquist, N.; Cohn, M.T.; Lindqvist, R.; Barker, G.C.; Rådström, P. The formation of Staphylococcus aureus enterotoxin in food environments and advances in risk assessment. Virulence 2011, 2, 580-592. [CrossRef] 
71. Mena, K.D.; Gerba, C.P. Risk assessment of pseudomonas aeruginosa in water. Rev. Environ. Contam. Toxicol. 2009, 201, 71-115. [CrossRef]

72. Al-Snafi, A.E. The chemical constituents and pharmacological effects of Capsella bursa-pastoris-A review. Int. J. Pharmacol. Toxicol. 2015, 5, 76-81.

73. Boscaro, V.; Boffa, L.; Binello, A.; Amisano, G.; Fornasero, S.; Cravotto, G.; Gallicchio, M. Antiproliferative, Proapoptotic, Antioxidant and Antimicrobial Effects of Sinapis nigra L. and Sinapis alba L. Extracts. Molecules 2018, 23, 3004. [CrossRef] [PubMed]

74. Saladino, F.; Bordin, K.; Luciano, F.B.; Franzón, M.F.; Mañes, J.; Meca, G. Antimicrobial Activity of the Glucosinolates. In Reference Series in Phytochemistry; Springer Science and Business Media B.V.: Dordrecht, The Netherlands, 2017; pp. $249-274$.

75. Melrose, J. The Glucosinolates: A Sulphur Glucoside Family of Mustard Anti-Tumour and Antimicrobial Phytochemicals of Potential Therapeutic Application. Biomedicines 2019, 7, 62. [CrossRef]

76. Dungey, S.G.; Sang, J.P.; Rothnie, N.E.; Palmer, M.V.; Burke, D.G.; Knox, R.B.; Williams, E.G.; Hilliard, E.P.; Salisbury, P.A. Glucosinolates in the pollen of rapeseed and indian mustard. Phytochemistry 1988, 27, 815-817. [CrossRef]

77. Avato, P.; Argentieri, M.P. Brassicaceae: A rich source of health improving phytochemicals. Phytochem. Rev. 2015, 14, 1019-1033. [CrossRef]

78. Ştefanescu, B.E.; Szabo, K.; Mocan, A.; Crisan, G. Phenolic compounds from five ericaceae species leaves and their related bioavailability and health benefits. Molecules 2019, 24, 2046. [CrossRef]

79. Singleton, V.L.; Orthofer, R.; Lamuela-Raventós, R.M. Analysis of total phenols and other oxidation substrates and antioxidants by means of folin-ciocalteu reagent. Methods Enzymol. 1999, 299, 152-178. [CrossRef]

80. Hassan, S.M.; Al Aqil, A.A.; Attimarad, M. Determination of crude saponin and total flavonoids content in guar meal. Adv. Med. Plant Res. 2013, 1, 24-28.

81. Stagos, D.; Portesis, N.; Spanou, C.; Mossialos, D.; Aligiannis, N.; Chaita, E.; Panagoulis, C.; Reri, E.; Skaltsounis, L.; Tsatsakis, A.M.; et al. Correlation of total polyphenolic content with antioxidant and antibacterial activity of 24 extracts from Greek domestic Lamiaceae species. Food Chem. Toxicol. 2012, 50, 4115-4124. [CrossRef]

82. Cano, A.; Acosta, M.; Arnao, M.B. A method to measure antioxidant activity in organic media: Application to lipophilic vitamins. Redox Rep. 2000, 5, 365-370. [CrossRef]

83. Szweda, P. Antimicrobial Activity of Honey. In Honey Analysis; InTech: London, UK, 2017. 